Rev. Bras. Saúde Prod. Anim., Salvador, v.15, n.1, p.261-269 jan./mar., 2014 http://www.rbspa.ufba.br ISSN 15199940

\title{
Genetic profile of Holstein and Jersey dairy bull lines available in Brazil
}

\author{
Perfil genético das linhagens de touros leiteiros Holandês e Jersey disponíveis no \\ Brasil
}

\begin{abstract}
GAYA, Leila de Genova ${ }^{1 *}$; CUCCO, Diego de Córdova ${ }^{2}$; LORENTZ, Leandro Homrich $^{3}$; SOARES, Marcio Pereira ${ }^{4}$; BATISTEL, Fernanda ${ }^{5}$; TICIANI, Elvis ${ }^{6}$; CAPELESSO, Alsiane ${ }^{7}$; ROVADOSCKI, Grégori Alberto ${ }^{5}$; TARÔCO, Graziela ${ }^{1}$; MADUREIRA, Ana Paula ; PÉRTILE, Simone Fernanda $\mathrm{Nedel}^{5}$; ZABOT, Valdirene ${ }^{8}$; DOMENICO, Quêti di ${ }^{2}$
\end{abstract}

\footnotetext{
${ }^{1}$ Universidade Federal de São João del-Rei, Departamento de Engenharia de Biossistemas, São João delRei, Minas Gerais, Brasil.

${ }^{2}$ Universidade do Estado de Santa Catarina, Centro de Educação Superior do Oeste, Departamento de Zootecnia, Chapecó, Santa Catarina, Brasil.

${ }^{3}$ Universidade Federal do Pampa, Itaqui, Rio Grande do Sul, Brasil.

${ }^{4}$ Instituto Federal de Educação, Ciência e Tecnologia Catarinense, Araquari, Santa Catarina, Brasil.

${ }^{5}$ Universidade de São Paulo, Escola Superior de Agricultura Luiz de Queiroz, Piracicaba, São Paulo, Brasil.

${ }^{6}$ Unive.rsidade do Estado de Santa Catarina, Centro de Ciências Agroveterinárias, Lages, Santa Catarina, Brasil

${ }^{7}$ Universidade Federal de Santa Maria, Centro de Ciências Rurais, Santa Maria, Rio Grande do Sul, Brasil.

${ }^{8}$ Universidade Comunitária da Região de Chapecó, Centro de Ciências Exatas e Ambientais, Chapecó, Santa Catarina, Brasil.

*Endereço para correspondência: lggaya@yahoo.com.br
}

\section{SUMMARY}

The Holstein and Jersey dairy cattle breeds are among the most prevalent in Brazil. To evaluate differences among the PTAs (predicted transmitting abilities) of these breeds and their lines, data were collected on 385 Holstein bulls and 82 Jersey sires with semen commercially available from nine Brazilian companies. Three different sire lines for each breed were found. The general linear models method was used for the comparison among lines and between breeds. The two most prevalent lines of Holstein breed presented higher average PTAs for milk yield (1,061.04 pounds and 975.32 pounds) and lower PTAs for percentage of milk solids (from $-0.05 \%$ to $-0.0003 \%)(\mathrm{P}<0.05)$. These results indicate the supply of sires that mostly increase the milk yield in the Brazilian market. The Jersey breed presented a higher inbreeding coefficient $(6.62 \%)$ than the Holstein breed (5.14\%) $(\mathrm{P}<0.05)$. Although the Holstein breed presented higher PTAs for milk yield and lower PTAs for percentage of milk solids $(\mathrm{P}<0.05)$, the productive life of the Jersey breed (1.17 months) was longer than it was in the Holstein breed $(0.40$ months $)(\mathrm{P}<0.05)$. We identified the existence of an important variability of the available genetic profiles, what allows the Brazilian producers to choose the most adequate semen for their production system. It is necessary to consider the genetic profiles of sires' lines offered for artificial insemination in Brazil to understand and direct the genetic pattern of Brazilian dairy cattle.

Keywords: animal breeding, dairy cattle, semen

\section{RESUMO}

As raças de bovinos de leite Holandesa e Jersey estão entre as mais prevalentes no Brasil. Para avaliar as diferenças entre as PTAs (habilidades de transmissão preditas) destas raças e suas linhagens, foram coletadas informações de 385 touros Holandês e 82 touros Jersey disponibilizados por nove empresas comercializadoras de sêmen no Brasil. Três diferentes linhagens de cada raça foram encontradas. $\mathrm{O}$ método dos modelos lineares 
generalizados foi utilizado para a comparação entre linhagens e entre raças. As duas linhagens da raça Holandesa mais prevalentes apresentaram as maiores PTAs médias para produção de leite (1.061,04 libras e 975,32 libras) e as menores PTAs para a porcentagem de sólidos no leite (de $-0,05 \%$ a $-0,0003 \%$ ) $(\mathrm{P}<0.05)$. Estes resultados sugerem a oferta de touros no mercado nacional que são capazes principalmente de aumentar a produção de leite. A raça Jersey apresentou um coeficiente de endogamia mais elevado $(6,62 \%)$ que o da raça Holandesa $(5,14 \%) \quad(\mathrm{P}<0.05)$. Embora a raça Holandesa tenha apresentado maiores PTAs para produção de leite e as menores PTAs para a porcentagem de sólidos no leite, a vida produtiva da raça Jersey apresentou-se mais longa $(1,17$ meses $)(\mathrm{P}<0.05)$ que a da raça Holandesa (0,40 meses). Houve uma importante variabilidade do material genético disponível, permitindo a escolha do sêmen mais adequado para cada sistema de produção. Faz-se necessário conhecer o perfil genético dos touros disponibilizados para inseminação artificial no Brasil, com vistas ao conhecimento e direcionamento do padrão genético dos bovinos leiteiros no país.

Palavras-chave: bovinos de leite, melhoramento animal, sêmen

\section{INTRODUCTION}

Brazil had an annual increase in milk production of approximately 4 to $6 \%$ over the last decade. Nevertheless, the country still imports more milk and dairy products than it exports (CARVALHO, 2010). This indicates the need for increased productivity and management, both of which are challenging factors in achieving sustainability and competitiveness in the dairy cattle industry (RUEDA et al., 2003).

Holstein and Jersey breeds account for 77.33 and $20.07 \%$, respectively, of the total imported semen used in 2008, with more than 2.5 million doses commercialized in Brazil (ASBIA, 2008). Various target traits are used in the selection process, and the genetic improvement of cattle is indispensable for increasing their productivity (MARK, 2004).

Artificial insemination, using semen from tested (or proven) sires, has been used to improve the production indices of Brazilian livestock. Tests showing the predicted transmitting abilities (PTAs) of bulls for traits of interest are conducted by the International Committee known as "Interbull" and are available in the "Dairy Bulls" (MARK, 2004; VANRADEN \& SULLIVAN, 2010) report. These tests quantify the individuals' breeding value, of which $50 \%$ represents the PTA, which is the basis of animal selection.

According to Madalena (2008) and Coleman et al. (2010), the selection of dairy cattle worldwide is mainly determined by the milk yield, including milk solids and quality, because the percentages of solids in milk are important for the production of dairy products. In Brazil, the milk yield is the most important selection criterion (CAMPOS et al., 2012), despite the increase of the reward for milk solids and quality in the Brazilian market (ROMA JÚNIOR et al., 2009). Therefore, it is important to the industry to investigate and to available bull lines with adequate profiles, improving its marketing opportunities. Studies about these profiles are not found in literature. Then, the objective of this study was to evaluate the variability of the genetic profile of Holstein and Jersey dairy bull breeds and lines with semen commercially available from Brazilian companies, aiming at advising the dairy cattle industry and the Brazilian producers about the pattern of the dairy cattle genetic resources available in Brazil by the semen companies. 


\section{MATERIAL AND METHODS}

The records of all bulls with available semen in Brazil in April 2008 were found on the websites of nine commercial dairy bulls semen companies. As a first initiative of a survey about the variability of the genetic profile of Holstein and Jersey dairy bull in Brazil, data regarding 385 Holstein sires and 82 Jersey sires were located and tabulated from the "Dairy Bulls" website (http://www.dairybulls.com), from the American genetic database, whose evaluations are performed by the combination of data from different countries. The database created contained information on the inbreeding coefficient and the PTAs for several traits of each of the bulls. The "Dairy Bulls" website was also used to identify the ancestral lines of the sires, what were added to the database. All the sires of both breeds with semen in Brazil were located in the "Dairy Bulls" website and the unique criterion to choose the sires was to have semen available in Brazil, regardless of their ranking in the genetic evaluation.

The traits were chosen to represent the groups of production, management, linear and type traits and are described below, as reported in the Interbull Centre (http://interbull.slu.se/www/v1/), the Council on Dairy Cattle Breeding (https://www.cdcb.us/) and the Holstein Association of the United States of America (http://www.holsteinusa.com/). Daughter Pregnancy Rate (DPR) is given by the number of non-pregnant cows that become pregnant during 21day period, after insemination, in percentage. The lower the pregnancy rates, the fewer the pregnant cows. Productive Life (PL) is given by the number of months that cows remain in production, in their first 7 years, compared to the average longevity of the sires, with a limit of 10 months for each lactation. Milk Yield (MY), Fat Yield (FY) and Protein Yield (PY), regarding the 305-day lactation period, were given in pounds, and Fat Concentration (FC) and Protein Concentration (PC), were given in percentage. Somatic Cells Score (SCC) is the score relative to the number of somatic cells in a microliter of milk. The higher the number of somatic cells, the higher the score for this trait.

Fore Udder Attachment (FUA) is given by the strengh of the attachment of the fore udder to the abdominal wall. The smoother the fore udder blends into the body wall, the higher the score for this trait. Rear Udder Height (RUH) is the distance from the vulva and milk secreting tissue measured in centre of udder in relation to height of the animal. The higher the rear udder, the higher the score for this trait. Rear Udder Width (RUW) is evaluated at the point of the udder attachment, and the wider the rear udder, the higher the score for this trait. Udder Depth (UD) is the distance from the udder floor to the ground relative to the hocks. The shallower the udder, the higher the score for udder depth. Udder Cleft (UC) is formed by the median suspensory ligament, which divides the udder lenght-wise into two distinct halves. The deeper the cleft, the higher the score for udder cleft.

For Rear Leg Side View (RLSV), the more sickle the legs, the higher the score for this trait. For Rear Leg Rear View (RLRV), the more parallel the legs, the higher the score for this trait. Foot Angle (FA) is the angle at the front of the rear hoof measured from the floor to the hairline at the right hoof. The steeper the angle, the higher the score for this trait. Feet and Legs Score (FLS) is a multi-trait score evaluated in 
Holstein breed that combines feet and rear legs evaluations.

Inbreeding Coefficient (IC) is defined as the probability of two alleles present at a given locus be identical by descent, that is to say, are derived by replication of a single allele from a common ancestor. An increased inbreeding coefficient indicates an increase in the homozygosity of individual genomes. Total Performance Index (TPI) is a multitrait index that combines PTAs for production, Management, Linear and Type Traits, thus ranking sire on their ability to transmit a balance of these traits.

The descriptive statistics, number of observations, mean, standard deviation, median, and the minimum and maximum values for the traits were estimated using the statistical package SAS, version 8 (STATISTICAL ANALYSIS SYSTEM, 1999) with the PROC MEANS procedure. The general linear models method and the Tukey test $(\mathrm{P}<0.05)$ were used for means comparison of PTAs among sire lines and between the two breeds, using the PROC GLM procedure from the same software. Records without information for the traits studied were removed prior to analysis.

\section{RESULTS AND DISCUSSION}

Tables 1 and 2 show the descriptive statistics of the PTAs for the evaluated traits of Holstein and Jersey breeds, respectively.

Three different Holstein sire lines commercially available from Brazilian companies were identified: Pabst Korndyke Star, North Star Joe Homestead and Mechthildes Sir Henry
Of Maplw. The Mechthildes Sir Henry Of Maplw and North Star Joe Homestead lines were bred 21 and 16 generations, respectively. Each of these two lines was bred by only one sire until the tenth generation, which denotes the high influence of an unique founder on these lines and both presented sires in each of the last four generations. The Pabst Korndyke Star line was bred 14 generations. The semen of the two last generations of this line was available in the Brazilian market, and the first three generations of this line were bred by only one sire.

The Holstein lines presented different profiles of PTAs for Daughters Pregnancy Rate, Milk Yield, Fat Concentration, Protein Concentration, Fore Udder Attachment, Rear Udder Width and Rear Leg Side View $(\mathrm{P}<0.05)$ (Table 3). The PTAs among the studied lines did not differ in their milk solids content and other variables $(\mathrm{P}>0.05)$.

The sire line North Star Joe Homestead was observed most often in the Brazilian market, making up approximately $53 \%$ of the semen available in the studied period. This line was characterized by high PTAs for milk yield and low PTAs for fat and concentrations $(\mathrm{P}<0.05)$. Therefore, we conclude that the profile of the semen offered by the companies in Brazil supports and facilitates the desired productive profile of increased milk yield. It is in according to Campos et al. (2012) that reports that the breeding selection process in Brazil still prioritizes a high milk yield, which is different from the global trend, although regardless of the increasing tendency of payment for milk quality in Brazil (ROMA JÚNIOR et. al, 2009). 
Rev. Bras. Saúde Prod. Anim., Salvador, v.15, n.1, p.261-269 jan./mar., 2014 http://www.rbspa.ufba.br ISSN 15199940

Table 1. Number of observations $(\mathrm{N})$, mean (M), standard deviation (SD), median (MED), maximum (MAX) and minimum (MIN) values for the PTAs (predicted transmitting abilities) in evaluated Holstein dairy bulls

\begin{tabular}{|c|c|c|c|c|c|c|}
\hline Trait* & $\mathrm{N}$ & $\mathrm{M}$ & SD & MED & MAX & MIN \\
\hline DPR (\%) & 370 & -0.94 & 1.36 & -0.90 & 3.30 & -5.60 \\
\hline PL (months) & 338 & 0.40 & 2.19 & 0.10 & 6.70 & -5.30 \\
\hline MY (pounds) & 381 & 981.51 & 634.34 & 943.00 & 2,869 & $-1,050$ \\
\hline FY (pounds) & 380 & 28.22 & 24.53 & 27.00 & 89.00 & -47.00 \\
\hline PY (pounds) & 380 & 28.14 & 17.82 & 27.00 & 80.00 & -26.00 \\
\hline $\mathrm{FC}(\%)$ & 368 & -0.03 & 0.09 & -0.03 & 0.20 & -0.24 \\
\hline PC (\%) & 334 & -0.005 & 0.05 & 0.00 & 0.11 & -0.19 \\
\hline FUA (points) & 378 & 1.06 & 1.03 & 0.98 & 3.91 & -1.48 \\
\hline RUH (points) & 380 & 1.31 & 1.08 & 1.35 & 4.14 & -1.80 \\
\hline RUW (points) & 380 & 1.31 & 1.03 & 1.31 & 3.80 & -1.44 \\
\hline UD (points) & 380 & 0.79 & 1.13 & 0.83 & 4.22 & -2.44 \\
\hline UC (points) & 378 & 1.01 & 1.13 & 1.07 & 3.76 & -2.28 \\
\hline RLSV (points) & 380 & -0.49 & 1.19 & -0.43 & 2.82 & -4.56 \\
\hline RLRV (points) & 380 & 1.30 & 1.64 & 1.21 & 23.08 & -2.18 \\
\hline FA (points) & 379 & 0.96 & 1.10 & 0.93 & 3.96 & -2.21 \\
\hline FLS (points) & 375 & 0.99 & 0.84 & 1.00 & 3.71 & -1.45 \\
\hline $\mathrm{SCC}$ & 381 & 2.98 & 0.18 & 2.97 & 3.70 & 0.00 \\
\hline $\mathrm{IC}(\%)$ & 385 & 5.14 & 2.08 & 4.80 & 15.20 & 1.10 \\
\hline TPI & 380 & $1,438.53$ & 190.12 & $1,456.50$ & 2,026 & 0.00 \\
\hline
\end{tabular}

*DPR $=$ Daughter Pregnancy Rate; PL $=$ Productive Life; MY $=$ Milk Yield; FY $=$ Fat Yield; $\mathrm{PY}=$ Protein Yield; $\mathrm{FC}=$ Fat Concentration; $\mathrm{PC}=$ Protein Concentration; FUA $=$ Fore Udder Attachment; RUH = Rear Udder Height; RUW = Rear Udder Width; UD = Udder Depth; UC = Udder Cleft; RLSV = Rear Leg Side View; RLRV = Rear Leg Rear View; FA = Foot Angle; FLS = Feet and Legs Score; $\mathrm{SCC}=$ Somatic Cells Score; IC = Inbreeding Coefficient; TP I= Total Performance Index.

Table 2. Number of observations (N), mean (M), standard deviation (SD), median (MED), maximum (MAX) and minimum (MIN) values for the PTAs (predicted transmitting abilities) in evaluated Jersey dairy bulls

\begin{tabular}{lcccccc}
\hline Trait* & $\mathrm{N}$ & $\mathrm{M}$ & $\mathrm{SD}$ & $\mathrm{MED}$ & $\mathrm{MAX}$ & $\mathrm{MIN}$ \\
\hline DPR (\%) & 77 & -0.45 & 0.99 & -0.35 & 2.30 & -3.30 \\
PL (months) & 79 & 1.17 & 1.62 & 1.10 & 4.80 & -2.70 \\
MY (pounds) & 79 & 644.54 & 529.32 & 584.00 & $1,883.00$ & -898.00 \\
FY (pounds) & 79 & 30.76 & 17.78 & 33.00 & 75.00 & -28.00 \\
PY (pounds) & 79 & 21.89 & 14.68 & 24.00 & 59.00 & -28.00 \\
FC (\%) & 76 & 0.009 & 0.13 & 0.01 & 0.29 & -0.31 \\
PC (\%) & 74 & -0.004 & 0.06 & 0.00 & 0.11 & -0.12 \\
FUA (points) & 80 & 0.87 & 0.74 & 0.80 & 2.40 & -1.40 \\
RUH (points) & 80 & 1.40 & 0.70 & 1.45 & 3.10 & -0.50 \\
RUW (points) & 82 & 1.08 & 0.61 & 1.20 & 2.40 & -0.20 \\
UD (points) & 80 & 0.62 & 1.09 & 0.70 & 2.90 & -2.00 \\
UC (points) & 78 & 0.51 & 0.69 & 0.50 & 2.20 & -2.10 \\
RLSV (points) & 75 & -0.02 & 0.50 & 0.00 & 1.00 & -1.70 \\
FA (points) & 74 & 0.75 & 0.48 & 0.40 & 1.80 & -0.50 \\
SCC & 79 & 2.98 & 0.12 & 2.98 & 3.25 & 0.00 \\
IC (\%) & 82 & 6.62 & 2.79 & 6.90 & 16.70 & 1.50 \\
TPI & 79 & 112.99 & 52.20 & 121.50 & 236.00 & -19.00 \\
\hline
\end{tabular}

*DPR $=$ Daughter Pregnancy Rate; PL = Productive Life; MY = Milk Yield; FY = Fat Yield; $\mathrm{PY}=$ Protein Yield; FC = Fat Concentration; $\mathrm{PC}=$ Protein Concentration; FUA = Fore Udder Attachment; RUH = Rear Udder Height; RUW = Rear Udder Width; UD = Udder Depth; UC = Udder Cleft; RLSV = Rear Leg Side View; FA = Foot Angle; SCC = Somatic Cells Score; IC = Inbreeding Coefficient; TPI = Total Performance Index. 
Rev. Bras. Saúde Prod. Anim., Salvador, v.15, n.1, p.261-269 jan./mar., 2014 http://www.rbspa.ufba.br ISSN 15199940

Table 3. Results of Tukey Test for the PTAs for the different lines of evaluated Holstein bulls

\begin{tabular}{|c|c|c|c|}
\hline \multirow[b]{2}{*}{ Trait* } & \multicolumn{3}{|c|}{ Holstein Lines } \\
\hline & $\begin{array}{c}\text { Pabst Korndyke } \\
\text { Star }\end{array}$ & $\begin{array}{l}\text { North Star Joe } \\
\text { Homestead }\end{array}$ & $\begin{array}{l}\text { Mechthildes Sir Henry Of } \\
\text { Maplw }\end{array}$ \\
\hline PN & 60 & 205 & 120 \\
\hline DPR (\%) & $-0.72^{\mathrm{a}}$ & $-0.86^{\mathrm{ab}}$ & $-1.19^{b}$ \\
\hline PL (months) & $0.31^{\mathrm{a}}$ & $0.37^{\mathrm{a}}$ & $0.49^{\mathrm{a}}$ \\
\hline MY (pounds) & $723.15^{b}$ & $1,061.04^{\mathrm{a}}$ & $975.32^{\mathrm{a}}$ \\
\hline FY (pounds) & $26.40^{\mathrm{a}}$ & $26.78^{\mathrm{a}}$ & $31.63^{\mathrm{a}}$ \\
\hline PY (pounds) & $25.85^{\mathrm{a}}$ & $28.39^{\mathrm{a}}$ & $28.89^{\mathrm{a}}$ \\
\hline $\mathrm{FC}(\%)$ & $-0.0002^{\mathrm{a}}$ & $-0.05^{b}$ & $-0.014^{\mathrm{a}}$ \\
\hline PC (\%) & $0.02^{\mathrm{a}}$ & $-0.01^{b}$ & $-0.0003^{b}$ \\
\hline FUA (points) & $1.19^{\mathrm{a}}$ & $1.19^{\mathrm{a}}$ & $0.74^{\mathrm{b}}$ \\
\hline RUH (points) & $1.11^{\mathrm{a}}$ & $1.42^{\mathrm{a}}$ & $1.22^{\mathrm{a}}$ \\
\hline RUW (points) & $1.08^{\mathrm{b}}$ & $1.49^{\mathrm{a}}$ & $1.12^{\mathrm{b}}$ \\
\hline UD (points) & $1.03^{\mathrm{a}}$ & $0.77^{\mathrm{a}}$ & $0.71^{\mathrm{a}}$ \\
\hline UC (points) & $1.15^{\mathrm{a}}$ & $1.05^{\mathrm{a}}$ & $0.858^{\mathrm{a}}$ \\
\hline RLSV (points) & $-0.19^{\mathrm{a}}$ & $-0.49^{\mathrm{ab}}$ & $-0.66^{b}$ \\
\hline RLRV (points) & $1.19^{\mathrm{a}}$ & $1.37^{\mathrm{a}}$ & $1.23^{\mathrm{a}}$ \\
\hline FA (points) & $0.89^{\mathrm{a}}$ & $1.01^{\mathrm{a}}$ & $0.90^{\mathrm{a}}$ \\
\hline FLS (points) & $1.00^{\mathrm{a}}$ & $0.95^{\mathrm{a}}$ & $1.06^{\mathrm{a}}$ \\
\hline SCC & $3.01^{\mathrm{a}}$ & $2.96^{\mathrm{a}}$ & $2.99^{\mathrm{a}}$ \\
\hline IC (\%) & $5.48^{\mathrm{a}}$ & $5.03^{\mathrm{a}}$ & $5.15^{\mathrm{a}}$ \\
\hline TPI & $1,425.78^{\mathrm{a}}$ & $1,445.61^{\mathrm{a}}$ & $1,432.68^{\mathrm{a}}$ \\
\hline \multicolumn{4}{|c|}{$\begin{array}{l}\text { *PN }=\text { Progeny Number in Interbull with semen available in Brazil; DPR = Daughter Pregnancy Rate; } \\
\text { PL = Productive Life; MY = Milk Yield; FY = Fat Yield; PY = Protein Yield; FC = Fat Concentration; } \\
\text { PC = Protein Concentration; FUA = Fore Udder Attachment; RUH = Rear Udder Height; RUW = Rear } \\
\text { Udder Width; UD = Udder Depth; UC = Udder Cleft; RLSV = Rear Leg Side View; RLRV = Rear Leg } \\
\text { Rear View; FA = Foot Angle; FLS = Feet and Legs Score; SCC = Somatic Cells Score; IC = Inbreeding } \\
\text { Coefficient; TPI = Total Performance Index. }\end{array}$} \\
\hline
\end{tabular}

Three different sire lines for the Jersey breed that were commercially available from Brazilian companies were identified: Welcome High Lawn Torono, Sparkle Supreme and Jester Standard Advancer. The progeny number in Interbull for each line with semen available in Brazil was 73 for Welcome High Lawn Torono, 6 for Sparkle Supreme and 3 for Jester Standard Advancer. The sire lines for the Jersey breed were not compared because two of the lines had low progeny and the statistical analysis would not be reliable. Both the Sparkle Supreme and Jester Standard Advancer sire lines were bred for 8 generations and presented sires in each of the last four generations in the Brazilian market. The first two generations of the Welcome High Lawn Torono and the Jester Standard Advancer lines were bred by only one sire. The Sparkle Supreme line was bred using only one sire until the fifth generation, indicating a high influence of an unique founder in this line. The Welcome High Lawn Torono line was bred for 9 generations, and the semen from the last four generations were available in the Brazilian market. This was the most important line for the Jersey breed 
commercialized in Brazil because it represented $89 \%$ of the total Jersey cows in the Brazilian market according to our results.

The reduced number of sire lines in Brazil and the concentration of most of the sires in only one line, may induce to a greater use of this line, what could increase the inbreeding coefficient, especially for the Jersey breed, if the matings are not properly conducted. Consequently, the increasing of the inbreeding coefficients may cause a reduction of milk, milk fat and milk protein yield (SOARES et al., 2011). Then, the importance of an appropriate orientation of the matings in Brazilian dairy cattle is previously known and is reinforced here.

Significant differences of performance were found between Holstein and Jersey breeds (Table 4). The Jersey breed had only one prevalent line in the Brazilian market and a greater inbreeding coefficient $(\mathrm{P}<0.05)$ than the Holstein breed. It could be probably due to an uncontrolled genealogy in the mating system used in this Jersey population or due to the intensive use of famous sires, as explained by Madalena (2008) in a report about the globalized inbreeding of breeds.

The productive life was higher for the Jersey breed even though the Holstein breed presented higher milk yield, in addition to a higher protein yield $(\mathrm{P}<0.05)$. The difference in productive life could be explained by the fact that cows with higher milk production tends to have shorter stayabilities (OLTENACU \& BROOM, 2010).

The fat concentration was lower for the Holstein breed $(\mathrm{P}<0.05)$, which was consistent with the observed pattern of cows with higher milk yield having a lower milk solids concentration (BOBE et al., 2007).
Table 4. Results of Tukey Test for the PTAs of evaluated Holstein and Jersey bulls

\begin{tabular}{|c|c|c|}
\hline \multirow{2}{*}{ Trait* } & \multicolumn{2}{|c|}{ Breed } \\
\hline & Holstein & Jersey \\
\hline $\operatorname{DPR}(\%)$ & $-0.94^{b}$ & $-0.45^{\mathrm{a}}$ \\
\hline PL (months) & $0.40^{\mathrm{b}}$ & $1.17^{\mathrm{a}}$ \\
\hline MY (pounds) & $981.51^{\mathrm{a}}$ & $644.54^{\mathrm{b}}$ \\
\hline FY (pounds) & $28.21^{\mathrm{a}}$ & $30.76^{\mathrm{a}}$ \\
\hline PY (pounds) & $28.14^{\mathrm{a}}$ & $21.89^{\mathrm{b}}$ \\
\hline $\mathrm{FC}(\%)$ & $-0.03^{b}$ & $0.009^{\mathrm{a}}$ \\
\hline $\mathrm{PC}(\%)$ & $-0.005^{\mathrm{a}}$ & $-0.004^{\mathrm{a}}$ \\
\hline FUA (points) & $1.06^{\mathrm{a}}$ & $0.87^{\mathrm{a}}$ \\
\hline RUH (points) & $1.31^{\mathrm{a}}$ & $1.42^{\mathrm{a}}$ \\
\hline RUW (points) & $1.31^{\mathrm{a}}$ & $1.08^{\mathrm{b}}$ \\
\hline UD (points) & $0.79^{\mathrm{a}}$ & $0.62^{\mathrm{a}}$ \\
\hline UC (points) & $1.00^{\mathrm{a}}$ & $0.51^{b}$ \\
\hline RLSV (points) & $-0.49^{b}$ & $-0.02^{\mathrm{a}}$ \\
\hline FA (points) & $0.96^{\mathrm{a}}$ & $0.48^{\mathrm{b}}$ \\
\hline $\mathrm{SCC}$ & $2.98^{\mathrm{a}}$ & $2.98^{\mathrm{a}}$ \\
\hline $\mathrm{IC}(\%)$ & $5.14^{\mathrm{b}}$ & $6.62^{\mathrm{a}}$ \\
\hline TPI & $1,438.53^{\mathrm{a}}$ & $112.99^{\mathrm{b}}$ \\
\hline$*$ DPR=Daughter & Pregnar & Rat \\
\hline $\mathrm{PL}=$ Productive & ife; Milk & $\mathrm{FP}=\mathrm{F}$ \\
\hline Yield; $\quad P P=$ & Protein $Y$ & $\mathrm{~A} ; \quad \mathrm{FC}=\mathrm{F}$ \\
\hline Concentration; & $\mathrm{C}=$ Protein & ncentratios \\
\hline $\mathrm{FUA}=$ Fore $\mathrm{Ud}$ & er Attachme & $\mathrm{RUH}=\mathrm{Re}$ \\
\hline Udder Height; & $\mathrm{UW}=$ Rear & Ader Widtl \\
\hline $\mathrm{UD}=$ Udder $\mathrm{I}$ & epth; UC = & dder Clef \\
\hline RLSV $=$ Rear L & g Side View & $\mathrm{RV}=\mathrm{Re}$ \\
\hline Leg Rear View & $\mathrm{FA}=$ Foot & gle; SCC \\
\hline Somatic Cells & Score; IC & Inbreedin \\
\hline Coefficient; TPI & $=$ Total Perfo & ince Index \\
\hline $\begin{array}{l}{ }^{\mathrm{ab}} \text { Means followe } \\
\text { same line are } \mathrm{n}\end{array}$ & by comn & tters on \\
\hline
\end{tabular}

Differences between the Holstein and Jersey breeds were also found for foot angle and rear udder width; the Holstein breed presented the highest values for both traits $(\mathrm{P}<0.05)$.

The means for rear leg side view and daughters pregnancy rate were negative and unfavorable in both the Holstein and Jersey breeds. However, the Jersey breed presented a better rear leg side view and daughter pregnancy rate than the Holstein breed $(\mathrm{P}<0.05)$.

Differences among Holstein and Jersey breeds genetic pattern were expected 
(VANRADEN et al., 2011), reinforcing the productive and reproductive pattern of each breed. Furthermore, genetic differences among the Holstein lines were identified, which allows the Brazilian producers to choose the most adequate semen for their production system, although a few lines have been identified in this research.

The profile of the most prevalent sire lines of dairy cattle on Brazilian market favors the genetic selection of Brazilian dairy cattle for high milk yield rather than solid contents. Thus, we emphasize that the genetic profile of the sires evaluated in this study conducted in 2008 is largely represented by the Holstein and Jersey dairy cows currently in production in Brazil.

Further and periodical studies to monitor the genetic variability of the commercially available Holstein and Jersey sire lines are necessary in order to apprise the industry and the producers about the pattern of the dairy cattle genetic resources available in Brazil by the semen companies, what might improve the Brazilian milk production and quality.

\section{REFERENCES}

\section{ASSOCIAÇÃO BRASILEIRA DE INSEMINAÇÃO ARTIFICIAL - ASBIA. Relatório Estatístico de Produção, Importação e Comercialização de Sêmen. Uberaba, 2008. Available at: $<$ http://www.asbia.org.br/download/mer cado/relatorio2008.pdf $>$. Accessed: Mar. 262014.}

BOBE, G.; LINDBERG, G.L.; FREEMAN, A.E.; BEITZ, D.C. Composition of milk and milk fatty acids is stable for cows differing in genetic merit for milk production.

Journal of Dairy Science, v.90, n.8, p.3955-3960, 2007.

CAMPOS, R.V.; COBUCI, J.A.; COSTA, C.N.; BRACCINI NETO, J. Genetic parameters for type traits in Holstein cows in Brazil. Revista Brasileira de Zootecnia, v.41, n.10, p.2150-2161, 2012.

CARVALHO, G. A indústria de laticínios no Brasil: passado, presente e futuro. Juiz de Fora: EMBRAPA, 2010. 12p. (Circular Técnica, 102).

COLEMAN, J.; PIERCE, K.M.; BERRY, D.P.; BRENNAN, A.; HORAN, B. Increasing milk solids production across lactation through genetic selection and intensive pasturebased feed system. Journal of Dairy Science, v.93, n.9, p.4302-4317, 2010.

MADALENA, F.E. How sustainable are the breeding programs of the global main stream dairy breeds? - The LatinAmerican situation. Livestock Research for Rural Development, v.20, n.2, 2008.

MARK, T. Applied Genetic Evaluations for Production and Functional Traits in Dairy Cattle. Journal of Dairy Science, v.87, n.8, p. 2641-2652, 2004.

OLTENACU, P.A.; BROOM, D.M. The impact of genetic selection for increased milk yield on the welfare of dairy cows.

Animal Welfare, v.19, p.39-49, 2010.

ROMA JÚNIOR, L.C.; MONTOYA, J.F.G.; MARTINS, T.T.; CASSOLI, L.D.; MACHADO, P.F. Sazonalidade do teor de proteína e outros componentes do leite e sua relação com programa de pagamento por qualidade. Arquivo Brasileiro de Medicina Veterinária e Zootecnia, v.61, n.6, p.1411-1418, 2009. 
RUEDA, B.L.; BLAKE, R.W.; NICHOLSON, C.F.; FOX, D.G.; TEDESCHI, L.O.; PELL, A.N.; FERNANDES, E.C.M.; VALENTIM, J.F.; CARNEIRO, J.C. Production and economic potentials of cattle in pasturebased systems of the western Amazon region of Brazil. Journal of Animal Science, v.81, p.2923-2937, 2003.

STATISTICAL ANALYSIS SYSTEM. User's Guide. Version 8. Cary: SAS Institute Inc., 1999. 1464p.

SOARES, M. P.; GAYA, L.G.; LORENTZ, L.H.; BATISTEL, F.; ROVADOSCKI, G.A.; TICIANI, E.; ZABOT, V.; DI DOMENICO, Q.; MADUREIRA, A.P.; PÉRTILE, S.F. Relationship between the magnitude of the inbreeding coefficient and milk traits in Holstein and Jersey dairy bull semen used in Brazil. Genetics and Molecular Research, v.10, n.3, p.19421947, 2011.
VANRADEN, P.M.; SULLIVAN, P.G. International genomic evaluation methods for dairy cattle. Genetics

Selection Evolution, v.42, n. 7, 2010.

VANRADEN, P. M.; OLSON, K.M.; WIGGANS, G.R.; COLE, J.B.; TOOKER, M.E. Genomic inbreeding and relationships among Holsteins, Jerseys, and Brown Swiss. Journal of Dairy Science, v.94, p.5673-5682, 2011.

Data de recebimento: 15/07/2013

Data de aprovação: 28/03/2014 